\title{
Hubungan Waktu Tunggu dan Cara Bayar terhadap Kepuasan Pasien Rawat Jalan Poli Penyakit Dalam Rumah Sakit PGI Cikini Jakarta
}

\author{
Hiliando Hasiholan ${ }^{1}$, Yanti Harjono Hadiwiardjo², Anisah ${ }^{3}$ \\ ${ }^{1}$ Program Studi Sarjana Kedokteran FK UPN Veteran Jakarta \\ ${ }^{2}$ Departemen Ilmu Kesehatan Masyarakat FK UPN Veteran Jakarta \\ ${ }^{3}$ Departemen Pendidikan Kedokteran UPN Veteran Jakarta
}

\begin{abstract}
Abstrak
Latar belakang: Rumah sakit adalah institusi kesehatan yang bertanggung jawab menyelenggarakan pelayanan kesehatan sesuai dengan standar mutu pelayanan rumah sakit yang berlaku. Mutu pelayanan rumah sakit dinilai dengan menilai tingkat kepuasan pasien yang dapat dipengaruhi beberapa faktor yaitu waktu tunggu dan cara bayar. Waktu tunggu pelayanan rawat jalan RS Cikini lebih dari 60 menit. Penelitian ini bertujuan untuk mengetahui hubungan waktu tunggu dan cara pembayaran dengan kepuasan pasien di Rawat Jalan Poli Penyakit Dalam RS Cikini Jakarta.

Metode: Studi cross sectional dilakukan pada Juli-Agustus 2019. Sampel penelitian sebanyak 78 pasien di rawat jalan poli penyakit dalam. Teknik pengambilan sampel dengan teknik consecutive sampling. Pada penelitian ini menggunakan instrumen berupa kuesioner untuk menilai kepuasan pasien. Data dianalisis menggunakan uji Kolmogorov-Smirnov

Hasil: Hasil univariat menunjukkan sebanyak 45 responden (57,7\%) waktu tunggu $<60$ menit dan 45 responden (57.7\%) merasa puas dengan pelayanan rawat jalan. Pasien BPJS dan Asuransi Swasta masing-masing sebanyak 39 responden (50\%). Uji penelitian menggunakan uji Kolmogorov-Smirnov sebagai uji alternatif dari uji chi-square, menunjukan tidak terdapat hubungan waktu tunggu terhadap kepuasan pasien rawat jalan penyakit dalam $(p=0,942)$. Hasil selanjutnya tidak terdapat hubungan cara bayar terhadap kepuasan rawat jalan penyakit dalam $(p=0,745)$.

Kesimpulan: Tidak terdapat hubungan waktu tunggu dan cara bayar terhadap kepuasan pasien rawat jalan penyakit dalam. Lamanya waktu tunggu dan adanya perbedaan cara bayar tidak mempengaruhi kepuasan pasien terhadap pelayanan rawat jalan karena ada faktor lain yang mempengaruhi kepuasan pasien.

Kata Kunci: Cara bayar, kepuasan, waktu tunggu

\section{Relationship of Waiting Time and Payments to The Satisfaction on Outpatients of Internal Medicine Clinic in PGI Cikini Hospital, Jakarta}

\begin{abstract}
Background: Hospital is a health institution that is responsible for organizing health services under applicable hospital service quality standard. The quality of hospital services is assessed by the level of patient satisfaction that can be affected by several factors like waiting time and payment methods. Waiting time in outpatient clinic Cikini Hospital is more than 60 minutes. This study aimed to determine the correlation between waiting time and payment method with patient satisfaction in the outpatient clinic of Internal Medicine, PGI Cikini Hospital, Jakarta.

Methods: A cross-sectional study was conducted between July and August 2019. The study sample was 78 patients in an outpatient clinic of internal medicine. The sampling technique with consecutive sampling technique. Data were analysis using Kolmogorov-Smirnov test.

Results: Univariate outcomes showed 45 respondents (57.7\%) waiting time <60 minutes and 45 respondents (57.7\%) were satisfied. Each BPJS patients and Private Insurance are 39 respondents (50\%). The research test using the Kolmogorov-Smirnov as an alternative test from chi-square test showed that there was no correlation between waiting time to the patient satisfaction of outpatients in internal medicine $(p=0,942)$. Other results there was no correlation between the payment method to the patient satisfaction of outpatients in internal medicine $(p=0,745)$.

Conclusion: No correlation between waiting time and payment method to the patient satisfaction of outpatients in internal medicine. The length of waiting time and the difference of payment method do not affect patient satisfaction with outpatient services because other factors affect patient satisfaction.

Keywords: Payment method, satisfaction, waiting time

Alamat Korespondensi :

Hiliando Hasiholan

Jl. RS Fatmawati, Pondok Labu, Jakarta Selatan 12450, Telp (021)7656971

Email: sianturi.hiliando@gmail.com
\end{abstract}




\section{PENDAHULUAN}

Salah satu institusi kesehatan yang menyelenggarakan upaya pelayanan kesehatan perorangan secara paripurna adalah rumah sakit, dimana salah satunya adalah menyediakan mutu pelayanan yang baik. Mutu pelayanan rumah sakit dapat dinilai melalui kepuasan pasien terhadap pelayanan kesehatan rumah sakit. Standar kepuasan pasien diatur dalam Kepmenkes No 129 Tahun 2008 tentang Standar Pelayanan Minimal Rumah Sakit. Standar kepuasan pasien khususnya rawat jalan dalam Kepmenkes adalah $\geq 90 \%{ }^{1}$

Berdasarkan penelitian sebelumnya terdapat faktor yang mempengaruhi tingkat kepuasan pasien adalah karakteristik dan sosidemografi pasien, teori SERVQUAL yaitu reliability, responsiveness, tangiable, assurance, dan empathy, dan humanitas, aksesibilitas, sumber biaya, dan total biaya yang dikeluarkan. $^{2}$ Lama menunggu dan kebersihan fasilitas kesehatan merupakan faktor dominan terhadap tingkat kepuasan pasien. Lama menunggu membuat pasien merasa jenuh dan bosan sehingga pasien merasa tidak nyaman. ${ }^{3}$ Survei pendahuluan yang telah dilakukan didapatkan waktu tunggu di RS Cikini lebih dari 60 menit, sehingga dikhawatirkan dapat mempengaruhi kepuasan pasien terhadap pelayanan RS Cikini Jakarta.

Sistem pembayaran yang berkembang di Indonesia saat ini adalah bayar tunai dan asuransi kesehatan. $^{4}$ Cara bayar seperti ini dapat mempengaruhi kepuasan pasien. $^{2}$ Pemerintah Indonesia saaat ini mengadakan Program Sistem Jaminan Sosial Nasional (SJSN) melalui Badan Penyelenggara Jaminan Sosial (BPJS). Model asuransi sosial yang ditanggung dan disediakan membuat perubahan dalam pelayanan kesehatan. ${ }^{5}$ Tahun 2018 BPJS mengeluarkan Laporan Pengelolaan Program dan Laporan Keuangan Jaminan Sosial Kesehatan Tahun 2017 dan hasil evaluasi kepuasan pasien peserta BPJS mencapai $79,5 \% .^{6}$

Rumah Sakit PGI Cikini Jakarta adalah RS Tipe B dengan akreditasi paripurna dan menjadi rumah sakit rujukan khususnya untuk penyakit ginjal. Kepuasan pasien akan pelayanan kesehatan di RS Cikini sebesar $83,5 \%^{7}$ dan melalui survei pendahuluan waktu menunggu pelayanan dokter di rawat jalan RS Cikini > 60 menit. RS Cikini menerima berbagai bentuk cara pembayaran, salah satunya asuransi swasta dan BPJS. Lama waktu tunggu dan cara bayar termasuk dalam salah satu dimensi kepuasan SERVQUAL yaitu reliability dan assurance. Penelitian ini dilakukan untuk mengetahui apakah terdapat hubungan waktu menunggu dan cara bayar dengan tingkat kepuasan pasien rawat jalan poli penyakit dalam RS Cikini.

\section{METODE}

Penelitian ini merupakan penelitian analitik observasional dengan desain penelitian potong lintang (cross sectional) dan dilakukan pada Juli sampai Agustus 2019. Penelitian ini dilakukan di ruang tunggu poli penyakit dalam Rumah Sakit PGI Cikini Jakarta. Populasi sumber adalah seluruh pasien rawat jalan yang berobat di Rumah Sakit PGI Cikini Jakarta. Sampel penelitian adalah pasien rawat jalan yang menunggu pelayanan di poli penyakit dalam yang diambil menggunakan teknik consecutive sampling. Jumlah sampel yang digunakan pada penelitian ini adalah sebanyak 78 sampel. Pengambilan data kepuasan pasien dilakukan dengan cara mengisi kuesioner yang sudah diuji validasi dan reliabilitasnya, sedangkan lama waktu tunggu melakukan observasi dan pencatatan durasi waktu menunggu dengan menggunakan jam tangan peneliti. Analisis statistik yang digunakan yaitu uji Kolmogorov-Smirnov sebagai uji alternatif dari uji chi-square.

\section{HASIL}

Sebanyak $47 \%$ pasien berusia $46-56$ tahun dengan $65 \%$ pasien berjenis kelamin perempuan dan pendidikan terakhir sarjana/diploma sebanyak 64\% (Tabel 1).

Tabel 1. Karakteristik Responden

\begin{tabular}{|c|c|c|}
\hline Karakteristik & $\mathbf{N}$ & $\%$ \\
\hline \multicolumn{3}{|l|}{ Jenis Kelamin } \\
\hline Laki-laki & 27 & $34,6 \%$ \\
\hline Perempuan & 51 & $65,4 \%$ \\
\hline \multicolumn{3}{|l|}{ Pendidikan } \\
\hline SMP & 3 & $3,8 \%$ \\
\hline SMA & 25 & $32,1 \%$ \\
\hline Sarjana & 50 & $64,1 \%$ \\
\hline \multicolumn{3}{|l|}{ Usia } \\
\hline $18-25$ & 6 & $7,7 \%$ \\
\hline $26-45$ & 22 & $28,2 \%$ \\
\hline $46-65$ & 37 & $47,4 \%$ \\
\hline$>65$ & 13 & $16,7 \%$ \\
\hline
\end{tabular}


Tabel 2. Distribusi Waktu Tunggu dan Cara Bayar Pasien Rawat Jalan Poli Penyakit Dalam

\begin{tabular}{lrr}
\hline Waktu tunggu (menit) & Jumlah & Persentase \\
\hline$<60$ & 45 & $57,7 \%$ \\
$61-120$ & 15 & $19,2 \%$ \\
$121-180$ & 5 & $6,4 \%$ \\
$181-240$ & 3 & $3,8 \%$ \\
$>240$ & 10 & $12,8 \%$ \\
\hline Cara bayar & & \\
Asuransi Swasta & 39 & $50,0 \%$ \\
BPJS & 39 & $50,0 \%$ \\
\hline
\end{tabular}

Pasien yang menunggu $\leq 60$ menit sebanyak 58\%, cara bayar 50\% menggunakan BPJS dan Asuransi Swasta, dan tingkat kepuasan pasien $57 \%$ puas dengan pelayanan rawat jalan poli penyakit dalam (Tabel 2). Dari analisis yang dilakukan didapatkan hasil $64 \%$ pasien merasa puas menunggu $\leq 60$ menit dan $48 \%$ pasien merasa puas menunggu $\geq 60$ menit dengan nilai $p$-value $=0,942$ yang berarti tidak terdapat hubungan antara waktu tunggu dengan kepuasan pasien rawat jalan poli penyakit dalam di RS PGI Cikini Jakarta. Didapatkan $64 \%$ pasien yang membayar dengan asuransi swasta merasa puas dan $51 \%$ pasien yang membayar dengan BPJS merasa puas dan didapatkan nilai $p$-value $=0,745$ yang berarti tidak terdapat hubungan antara cara bayar dengan tingkat kepuasan pasien rawat jalan poli penyakit dalam RS PGI Cikini Jakarta (Tabel 4).

Tabel 3. Hubungan Waktu Tunggu dengan Tingkat Kepuasan Pasien Rawat Jalan Poli Penyakit Dalam

\begin{tabular}{llllll}
\hline \multirow{2}{*}{$\begin{array}{c}\text { Waktu } \\
\text { Tunggu }\end{array}$} & \multicolumn{3}{c}{ Tingkat Kepuasan } & & Total \\
\cline { 2 - 4 } & $\begin{array}{l}\text { Cukup } \\
\text { Puas }\end{array}$ & Puas & $\begin{array}{l}\text { Sangat } \\
\text { Puas }\end{array}$ & & \\
\hline$<60$ & 1 & 29 & 15 & 45 & \\
menit & $(2,2 \%)$ & $(64,4 \%)$ & $(33,3 \%)$ & $(100 \%)$ \\
$>60$ & 2 & 16 & 15 & 33 & \\
menit & $(6,1 \%)$ & $(48,5 \%)$ & $(45,5 \%)$ & $(100 \%)$ & 0,942 \\
& 3 & 45 & 30 & & \\
Total & $(3,8 \%)$ & $(57,7 \%)$ & $(38,5 \%)$ & & \\
\hline
\end{tabular}

Tabel 4. Hubungan Cara Bayar dengan

Tingkat Kepuasan Pasien Rawat Jalan Poli Penyakit Dalam

\begin{tabular}{llllll}
\hline \multirow{2}{*}{$\begin{array}{c}\text { Cara } \\
\text { Bayar }\end{array}$} & \multicolumn{2}{c}{ Tingkat Kepuasan } & & \multirow{2}{*}{ Total } \\
\cline { 2 - 4 } & $\begin{array}{l}\text { Cukup } \\
\text { Puas }\end{array}$ & Puas & $\begin{array}{l}\text { Sangat } \\
\text { Puas }\end{array}$ & & \\
\hline Asuransi & 2 & 25 & 12 & 39 & \\
swasta & $(5,1 \%)$ & $(64,1 \%)$ & $(30,8 \%)$ & $(100 \%$ & \\
BPJS & 1 & 20 & 18 & 39 & 0 \\
& $(2,6 \%)$ & $(51,3 \%)$ & $(46,2 \%)$ & $(100 \%)$ & 0,745 \\
Total & 3 & 45 & 30 & & \\
& $(3,8 \%)$ & $(57,7 \%)$ & $(38,5 \%)$ & & \\
\hline
\end{tabular}

\section{PEMBAHASAN}

Penelitian ini mendapatkan $64,4 \%$ yang merasa puas dan tidak terdapat hubungan yang bermakna antara waktu tunggu dengan tingkat kepuasan pasien rawat jalan poli penyakit dalam. Hasil ini menunjukkan walaupun sebagian responden dengan waktu menunggu yang lama tetap merasa puas dengan pelayanan rawat jalan di poli penyakit dalam.

Hasil penelitian ini sesuai dengan penelitian Mayasari yang dalam penelitiannya menggunakan uji Chi-square mendapat hasil pvalue $=1(\mathrm{p}$-value $>0,05)$ memperlihatkan tidak terdapat hubungan waktu tunggu dengan kepuasan pasien rawat jalan. Menurut Mayasari walaupun harus menunggu lama pasien merasa puas karena pasien sudah terbiasa menunggu lama dalam upaya mendapatkan pelayanan rawat jalan dokter di poli penyakit dalam. ${ }^{8}$ Penelitian lain dilakukan oleh Hasan mengenai hubungan waktu tunggu dengan kepuasan pasien rawat jalan di poliklinik dengan uji spearman dan didapatkan tidak terdapat hubungan bermakna antara waktu tunggu dengan kepuasan pasien. Hal tersebut dapat dikarenakan terdapatnya faktor lain yang menyebabkan tidak terdapat hubungan waktu tunggu dengan kepuasan yaitu karena responden adalah pasien kunjungan berulang dan pasien dengan menggunakan asuransi. ${ }^{9}$ Penelitian Putri serupa dengan hasil penelitian ini dengan uji fisher didapatkan nlai $\mathrm{p}$-value $=1(\mathrm{p}$-value $>0,05)$. Hasil ini menunjukkan terdapat hubungan signifikan antara waktu tunggu dengan kepuasan pasien rawat jalan di RS Islam Ahmad Yani Surabaya. ${ }^{10}$ 
Hasil penelitian ini dan penelitian lainnya menunjukkan tidak terdapat perbedaan dan hubungan antara waktu tunggu terhadap kepuasan pasien rawat jalan. Hal ini disebabkan oleh banyaknya faktor yang bisa mempengaruhi kepuasan pasien seperti karakteristik responden (usia, pendidikan, jenis kelamin, status pernikahan), sumber biaya, keuangan pasien, dan mutu pelayanan (tangibles, responsiveness, reliability, assurance dan empathy) yang diberikan. $^{2}$ Waktu tunggu pasien tidak dikategorikan dalam cepat atau lambat tetapi dilihat dari lama waktu menunggunya. KepMenkes RI Tahun 2008 tentang Standar Pelayanan Minimal Rumah Sakit sudah mengatur tentang standar waktu tunggu adalah $\leq 60$ menit. Waktu tunggu bisa menjadi lama disebabkan oleh banyak faktor seperti dokter belum tiba di ruangan saat jam praktik sudah dimulai hingga banyaknya antrean pasien yang akan berobat. Pasien menunggu $<60$ menit disebabkan oleh dokter yang hadir tepat waktu dan pasien yang datang lebih awal, sedangkan pasien yang menunggu $>60$ menit bisa disebabkan oleh kedatangan pasien datang beberapa jam setelah jadwal praktik dokter dimulai dan antrean yang panjang karena banyak pasien yang datang. Walaupun tidak terdapat hubungan waktu tunggu dengan kepuasan pasien rawat jalan, rumah sakit harus tetap memperhatikan lama menunggu pasien. Hal ini perlu diperhatikan karena bila menunggu sangat lama pasien merasa jenuh dan bosan. ${ }^{1,3}$

Waktu tunggu pada mutu pelayanan termasuk dalam aspek reliability. Aspek reliability mencakup dengan kemampuan dalam memberikan pelayanan yang cepat, segera, dan akurat. $^{2}$ Suryawati mengatakan kepuasan pasien dapat dilihat dari dua sisi yaitu mengacu pada penerapan standar dan etika profesi dan mengacu pada penerapan pelayanan kesehatan. Namun untuk menilai kepuasan pasien perlu diperhatikan pelayanan yang diberikan oleh dokter dan perawat. $^{11}$ Hasil penelitian lain didapatkan bahwa pasien tetap puas meskipun waktu menunggu lama (>60 menit) karena mendapat pelayanan yang sangat baik dan memuaskan dari dokter dan perawat. Selain itu pasien sudah pernah mendapatkan pelayanan sebelumnya dari dokter atau perawat di rumah sakit tersebut sehingga pasien merasa nyaman untuk kembali berobat ke rumah sakit itu kembali. ${ }^{8}$ Kepuasan pasien terhadap pelayanan disebabkan oleh kemampuan interpersonal dan perilaku profesional dokter dan perawat yang sangat baik.

Penelitian ini menemukan $64,1 \%$ orang menggunakan asuransi swasta dan $53,1 \%$ responden BPJS yang merasa puas dengan pelayanan di rawat jalan poli penyakit dalam. Hasil uji statistik menggunakan uji Kolmogorov-Smirnov menunjukkan tidak terdapat hubungan bermakna antara cara bayar dengan tingkat kepuasan pasien yang berobat rawat jalan di poli penyakit dalam RS Cikini. Hasil ini menunjukkan pasien yang membayar dengan asuransi swasta maupun dengan BPJS sama- sama merasa puas dengan pelayanan rawat jalan di poli penyakit dalam.

Hasil pada penelitian ini sesuai dengan penelitian Musdalifah dkk. yang memperlihatkan tidak terdapat perbedaan signifikan antara kepuasan pasien Umum dengan pasien BPJS. ${ }^{12}$ Tidak terdapat perbedaan tersebut karena pasien JKN (BPJS) dan pasien umum mendapat perlakuan yang sama dari dokter dan perawat. Hasil penelitian lain dilakukan Firmasnyah dkk. bahwa tidak adanya perbedaan kepuasan antara pasien JKN dan pasien umum. Hal tersebut terjadi karena pelayanan yang diberikan petugas di rumah sakit tersebut adil dan tidak membeda-bedakan status pasien. ${ }^{13}$ Penelitian lain yang serupa dilakukan oleh Imelda juga mendapatkan hasil tidak ada perbedaan kepuasan di rawat inap antara pasien BPJS dan pasien Non BPJS di RSUP Adam Malik. ${ }^{14}$

Hasil penelitian ini dan penelitian lainnya menunjukkan tidak ada perbedaan dan hubungan yang bermakna terkait kepuasan pasien terhadap cara bayar pasien. Hal ini dapat disebabkan oleh adanya banyak faktor yang dapat mempengaruhi kepuasan pasien seperti karakteristik responden (umur, pendidikan, jenis kelamin, status pernikahan), sumber biaya dan keuangan pasien, dan mutu pelayanan (tangibles, responsiveness, reliability, assurance, dan empathy) yang diberikan. ${ }^{2}$ Suryawati menyatakan petugas kesehatan seperti dokter dan perawat sangatlah berpengaruh terhadap kepuasan pasien. Kemampuan interpersonal dokter dan perawat yang baik menjadi kunci dalam proses pengobatan pasien. Pasien menyukai dokter yang ramah dan sopan, mau mendengarkan, serta bisa menjelaskan kondisi pasien dengan bahasa yang sederhana. ${ }^{12}$

\section{KESIMPULAN}

Berdasarkan analisis dan pembahasan dari penelitian ini, maka dapat disimpulkan 
bahwa sebagian besar responden $(57,7 \%)$ memiliki waktu tunggu $<60$ dan merasa puas $(57,7 \%)$ dengan pelayanan di rawat jalan poli penyakit dalam RS PGI Cikini Jakarta. Sehingga didapatkan tidak terdapat hubungan waktu tunggu dan cara bayar terhadap kepuasan pasien rawat jalan poli penyakit dalam RS PGI Cikini Jakarta.

\section{DAFTAR PUSTAKA}

1. RI KK. Keputusan Menteri No 129 Tahun 2008 tentang Standar Pelayanan Minimal Rumah Sakit. 2008 p. 69-73. Available from: http://kesmas.kemkes.go.id/perpu/konten /uu/uu-nomor-44-tahun-2009-ttg-rs.

2. Budijanto D. Analisis Faktor-Faktor Yang Mempengaruhi Tingkat Kepuasan Responden Pengguna Rawat Jalan Rumah Sakit Pemerintah Dl Indonesia. 2007;10(2). Available from: http://ejournal.litbang.depkes.go.id/index .php/hsr/article/view/1781/2588

3. Herjunianto., Dewanto A. Pengaruh Waktu Tunggu terhadap Wait Satisfaction Pasien di Instalasi Rawat Jalan RSAL dr. Ramelan. J Apl Manaj [Internet]. 2014 [cited 2018 Nov 23];12(2):248-57. Available from: http://www.jurnaljam.ub.ac.id/index.php/ jam/article/view/646/653

4. Azwar A. Pengantar Administrasi Kesehatan: Edisi Ketiga. Jakarta: Binarupa Aksara; 2010.

5. Dahlan M, Setyopranoto I, Trisnantoro L. Evaluasi Implementasi Program Jaminan Kesehatan Nasional terhadap Pasien Stroke di RSUP Dr. Sardjito. J Kebijak Kesehat Indones. 2017;6(02):73-82. Available from: https://jurnal.ugm.ac.id/jkki/article/view/ 28934

6. Kesehatan B. Laporan Pengelolaan Program dan Laporan Keuangan Jaminan Sosial Kesehatan Tahun 2017 [Internet]. 2017. Available from: https://bpjskesehatan.go.id/bpjs/dmdocuments/5b8c 446214547b3f6727a710cd62dae7.pdf
7. Rumah Sakit PGI Cikini. Persentase Kepuasan Pelanggan [Internet]. 2017 [cited 2019 Apr 24]. Available from: http://www.rscikini.com/page/kepuasanpasien

8. Mayasari F. Analisis Hubungan Waktu Pelayanan dan Faktor Total Quality Service Terhadap Kepuasan Pasien di Poliklinik Kebidanan dan Kandungan RSIA Anugerah Medical Centre Kota Metro Tahun 2015. J Adm Rumah Sakit Indones [Internet]. 2015 May 4 [cited 2018 Nov 23];2(3). Available from: http://journal.fkm.ui.ac.id/arsi/article/vie $\mathrm{w} / 2203$

9. Hasan. Hubungan Waiting Times/Waktu Tunggu Dengan Kepuasan Pasien Di Poliklinik Mata Pada Instalasi Rawat Jalan Di Rsud Tarakan Propinsi Kalimantan Timur Tahun 2013 [Internet]. Universitas Hasanuddin; 2014 [cited 2019 May 19]. Available from: http://digilib.unhas.ac.id/uploaded_files/t emporary/DigitalCollection/MjI1OGE2 MzNiMWFmMjcwZTM5OTE2NTNIYT YwNDliODMyZmI1MmMyNw==.pdf

10. Veronica Juniarti Putri, Firdaus, Agus Aan Adriansyah. Hubungan Waktu Tunggu Pelayanan Dengan Kepuasan Pasien BPJS di Poli Rawat Jalan Rumah Sakit Islam Ahmad Yani Surabaya. Glob Heal Sci [Internet]. 2018 Dec 1 [cited 2019 Aug 4];3(4):387-93. Available from:

http://jurnal.csdforum.com/index.php/GH S/article/view/256/151

11. Suryawati C. Kepuasan Pasien Rumah Sakit (Tinjauan Teoritis dan Penerapannya pada Penelitian). J Manaj Pelayanan Kesehat. 2004;7(4). Available from:

https://jurnal.ugm.ac.id/jmpk/article/view $12913 / 2633$

12. Musdalifah M, Irwandy I, Maidin A. Analisis Perbedaan Kepuasan Pasien JKN dan Umum di RSUD Bantaeng Tahun 2015. J Kebijak Kesehat Indones JKKI [Internet]. 2016 Mar 1 [cited 2019 Aug 3];5(1):33-9. Available from: https://jurnal.ugm.ac.id/jkki/article/view/ 
$36082 / 21104$

13. Naufal Roby Firmansyah, Christyana

Sandra, Eri Witcahyo. Perbedaan Kepuasaan antara Pasien Peserta Jaminan Kesehatan Nasional dengan Umum Berdasarkan Mutu Pelayanan Kesehatan di Instalasi Rawat Inap RSD dr. Soebandi Jember. Artik Ilm Has Penelit Mahsiswa [Internet]. 2016 [cited 2019 Aug 3]; Available from: https://repository.unej.ac.id/bitstream/han dle/123456789/78414/R.Moh.Naufal
Roby Firmansyah.pdf? sequence $=1$

14. Imelda S, Nahrisah E. Analisis Tingkat Mutu Pelayanan Rawat Inap Dalam Upaya Peningkatan Kepuasan Pasien Di Rsup Adam Malik Medan (Studi Perbandingan Antara Pasien Umum Dan Pasien BPJS). J Ilm AMIK Labuhan Batu [Internet]. 2015 Sep 1 [cited 2019 Aug 2];3(3):33-44. Available from: http://ojs.amik-

labuhanbatu.ac.id/index.php/JIFOR/articl e/view/48/47 